\title{
Marine Wood Borers
}

\section{Little Known Crustaceans of Destructive Habits}

By Clyde H. Truesdale, Forest Products Laboratory, Madison, IVisconsin

Enormous destruction to timber structures is caused every year by the ravages of marine wood borers. These borers work in salt water throughout the entire length of the seacoast of the United States, but their ravages are particularly severe along the South Atlantic and Gulf coasts.

The damage is caused chiefly by two borers of the mollusk group, the xylotrya and teredo, and one of the crustacean group, the liminoria. The former are commonly refered to as "ship worms", and the latter is monly referred to " "ship v known to engineers and others who are concerned in the maintenance of wharves and other structures of wood in salt water.

There are, however, two other borers of the crustacean group that are known to be present on our seacoasts. These are called "chelura" and "sphaeroma." Chelura has been reported from only two places on our coast, Woodsholl, Mass., and Provincetown, Mass. Sphaeroma has been reported from several points on the South Atlantic and Gulf coasts-Crescent City, Fla., Milton, Fla., Bay Point, Fla., Palatka, Fla., Tampa, Fla., and Bayou Bonfoncia, La

The appearance of wood attacked by chelura is so similar to the work of liminoria that the identity of the former may have frequently escaped observation, the damage being attributed to liminoria. In $A$, Fig. 1, is shown a specimen of wood attacked by liminoria, and in $B$ one attacked by chelura. In each case

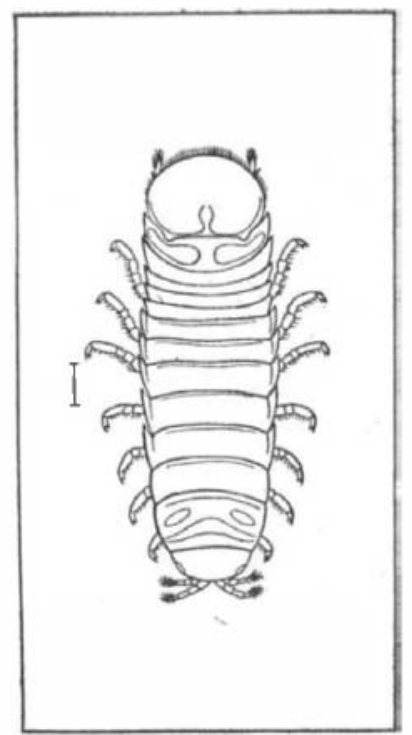

Fig. 3.-Liminoria lignorum.

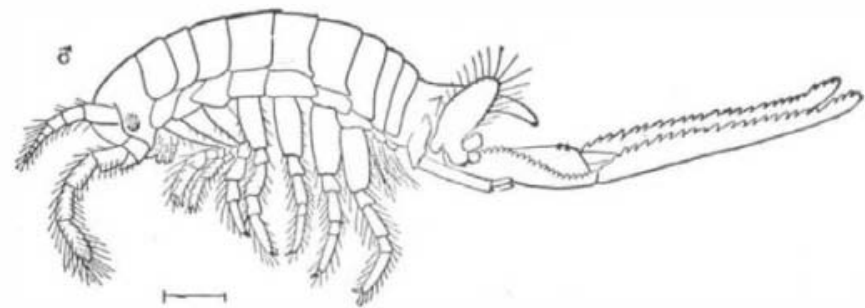

Fig. 4.-Chelura terebrans.

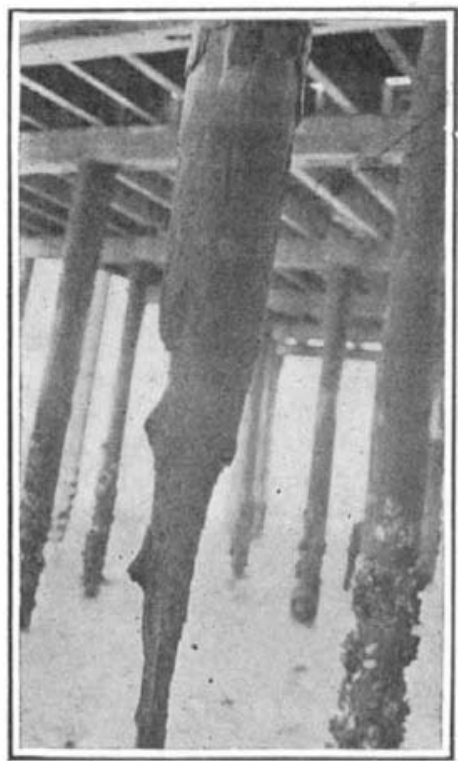

Fig. 7.-Longleaf pine pile Brunswick, Ga.

the size of the bore is about the same. Liminoria galleries usually extend inward, perpendicular to the surface. These are about $1 / 32$ inch to $1 / 16$ inch in diameter, and about $1 / 2$ inch deep. They lie side by side in countless numbers, the partitions between the galleries being so thin that the wood is easily broken

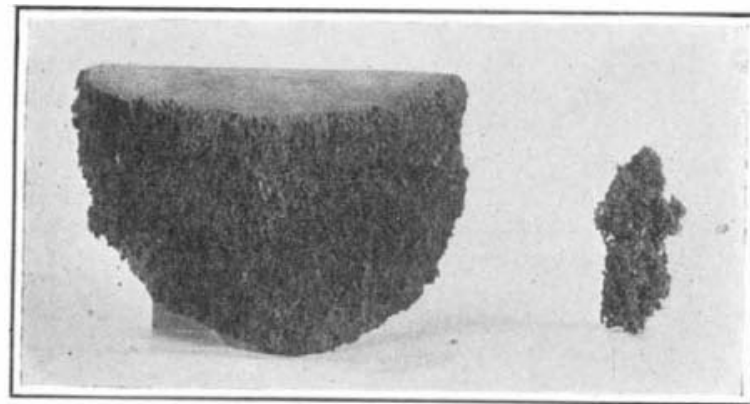

Fig. 1.-Wood attacked by liminoria (left) and chelura (right).

In the first the galleries run in radially and penetrate about $\%$ inch. In the second they run in all directions, and the entire wood structure has been penetrated.

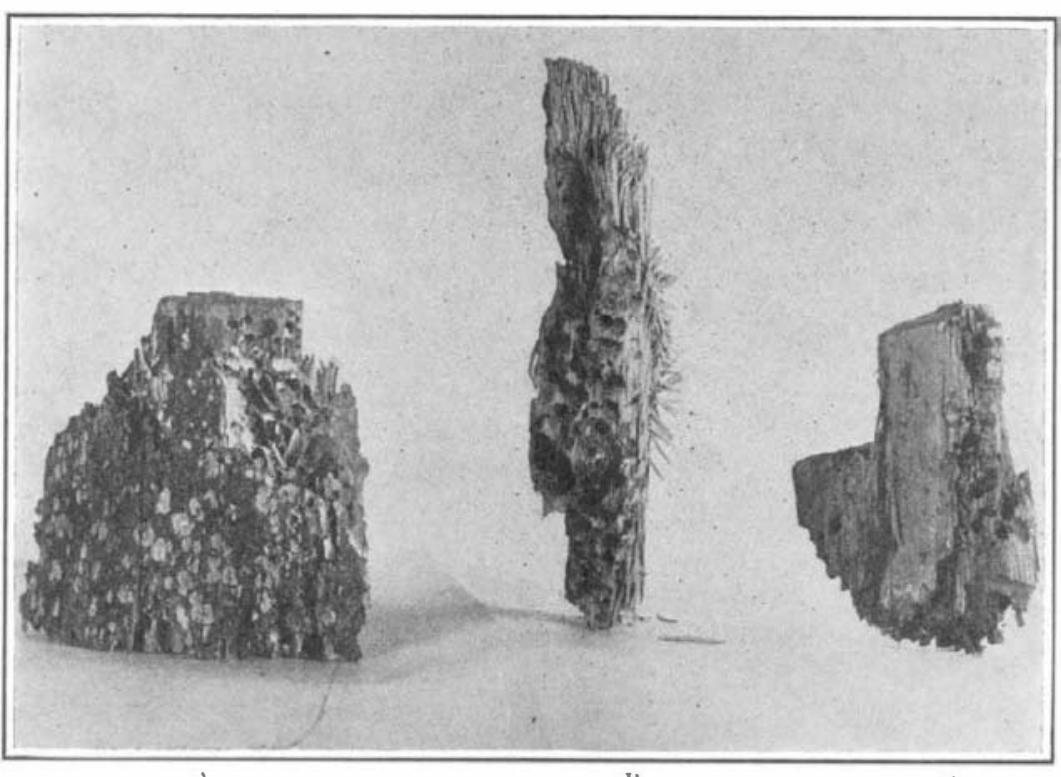

Fig. 2.-Wood attacked by shipworm (A) and sphaeroma (B and C). Note small entrances to galleries in $A$, and large entrances in $B$ and $C$. In $B$ is shown attack in palmetto.

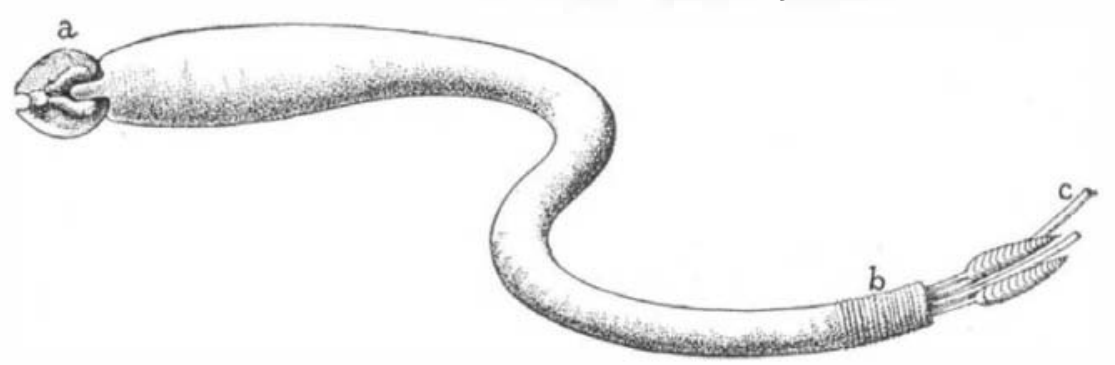

Fig. 5.-Xylotrya.

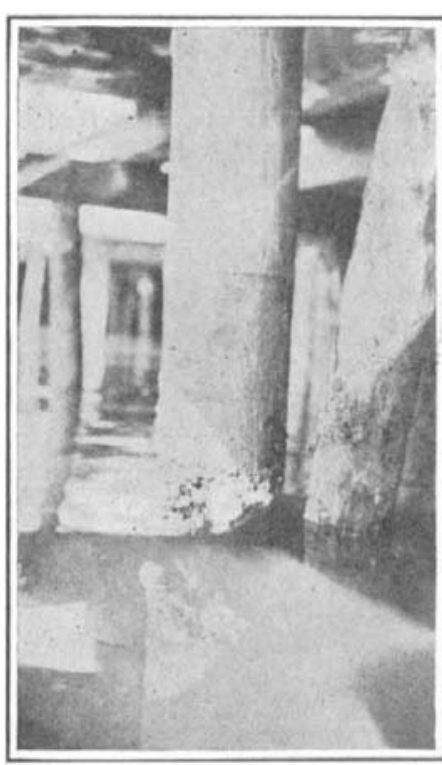

Fig. 8.-Longleaf pine pile destroyed by xylotrya at Pensacola, Fla. away by wave action, thus exposing new surface to attack. The chelura bore much deeper, and the galleries may run in all directions through the wood. They also attack the wood in great numbers, the walls between the galleries are very thin and the wood is easily broken away by wave action. As shown in the picture, the appearance of wood attacked by liminoria and chelura is very similar. Figs. 3 and 4 show specimens of liminoria and chelura very much enlarged. These borers are no larger than a small grain of rice. Liminoria excavates in wood both for food and shelter, boring being accomplished by very sharp mandibles. Chelura are somewhat similar to shrimp in appearance. They bore with an instrument somewhat resembling a file.

Xylotrya (Fig. 5) is very similar to teredo. These borers enter the wood when very small. As they penetrate the wood, however, they grow very rapidly and the galleries increase in size to accommodato the growing body. The galleries average about $3 / 8$ inch in diameter, and 3 inches to 6 inches in length, though under favorable conditions they may reach 1 inch in diameter and 4 or 6 inches in length. The exterior appearance of the surface of wood attacked by ship worms is often very trances to the galleries are 
no larger than a pin hole, and the wood may appear to be practically sound until it is cut into, when larg and numerous galleries are revealed. This is indicated quite clearly by $A$, Fig. 2 . These galleries are always lined by white calcareous material. They intertwine about each other and are usually so numerous that in severely attacked specimens the wood is rendered useless for any purpose. These borers have been known to utterly destroy pine piling in less than thirty days, while the average life of piling on the Gulf coast is les than two years, if the timber is not protected from them.

Sphaeroma has long been known to mankind, and is very common in many parts of the world. It was not until 1898 however that it was known to attack wod. until 1898 however that it was known to attack wood. by an unknown borer was taken from the St. John River, near Palatka, Fla., and sent to the Smithsonian Institution. It was identified as a species of sphaeroma and given the name of sphaeroma destructor. This borer (Fig. 6) is somewhat similar to the liminoria but very much larger. It is about $1 / 8$ inch to $1 / 4$ inch long, and excavates a round gallery about $1 / 8$ to $3 / 16$ inch in diameter. (The animal is larger than the gallery.) The gallery is of the same diameter throughout, and is usually about $1 / 2$ inch deep. Unlike the teredo gallery, there is no calcareous lining.

The galleries made by the sphaeroma are quite similar to those made by the shipworm (Fig. $2, B$ and $C$ ),

Electric Ignition Devices for Gas Engines

WE illustrate an electric device of a recent European design which is now applied very successfully for the ignition of large gas engines. The object of the apparatus, which is quite an elaborate one, though of reliable working, is to produce a quick break at the spark plug inside the engine so as to give the electric arc or spark such as the ignition of the gas requires. At the outside and upon the engine is a device for closing an electric circuit, and when this is done, the spark break is caused to oceur under the best conditions so as to causexplosion of the gas. The first part of the apparatus consists of an upright box mounted upon the end of the cam shaft as is seen in the main view, while a second photograph shows some of the details. This device secures the opening and closing of the electric circuits for each of the spark plugs. On the cam shaft is mounted a rotary contact piece, and upon it work the sets of brushes seen in the illustration. Various switching devices are lodged in the top part of the box Brushes are mounted in a brush-holder somewhat as in a dynamo, and the hand-wheel seen below allows of sliftin the brushes so as to regulate the moment of ignition. Besides this, the brushes can be each somewhat altered in position with reference to the others as to make any desired adjustment of the moment of ignition in the rear chamber in relation with the front chamber. Another small wheel at the side of the box regulates the duration of the electric contact, as this is required in engines which run at variable speed; for instance the large gas engines used with blast furnace

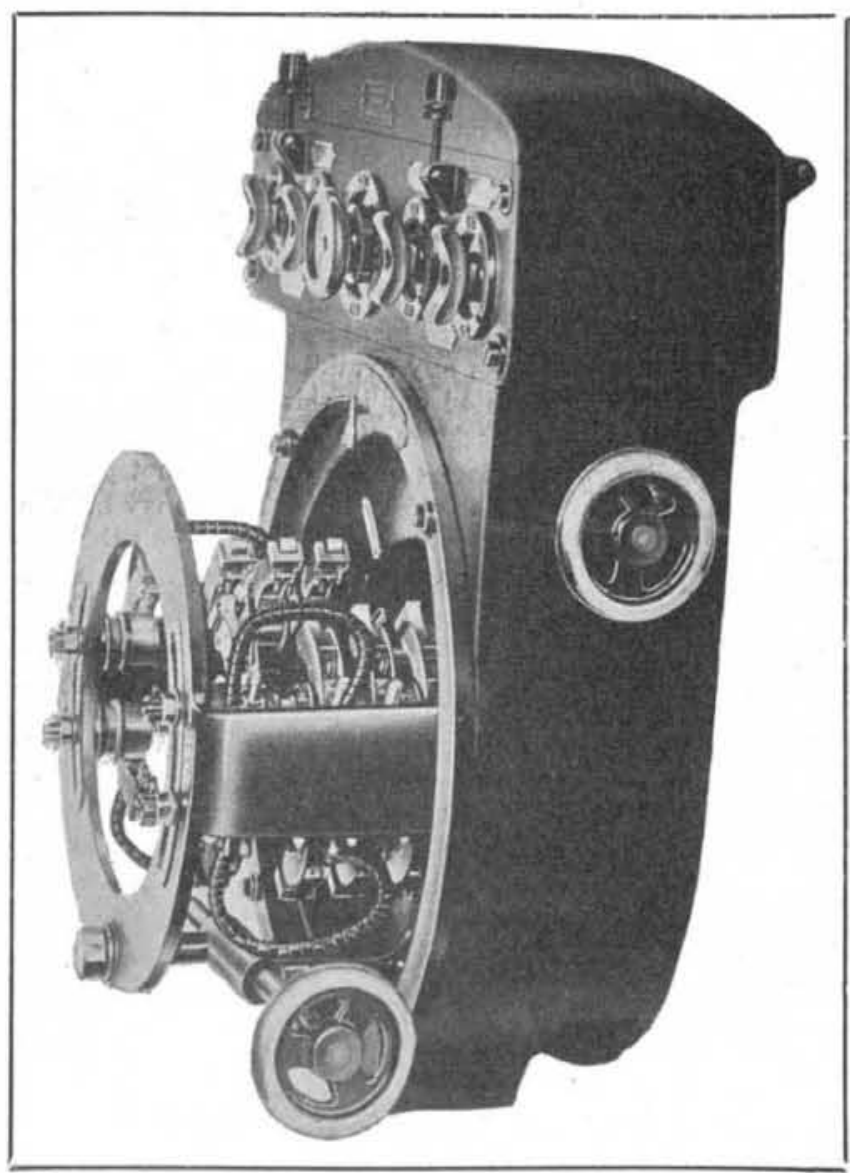

Rotary contact closer on end of camshaft, showing adjustable contact brushes. where the surface of the latter has been broken away by wave action. Unless one makes a minute examination of the wood, their work would naturally be attributed to the shipworms. This probably accounts for the fact that sphaeroma destructor was never identified until 1898, and has been reported from only two or three places since then. B, Fig. 2, shows the work of sphaeroma in palmetto, which is usually considered to resist the attack of the borers. C, Fig. 2, shows attack in a specimen of pine. These pictures show quite clearly the difference in the appearance of wood attacked by sphaeroma and shipworms. The most distinguishing feature is the difference in size of the entrance, and the fact that sphaeroma rarely bores more than $3 / 8$ or $1 / 2$ inch into the wood.

The damage done by sphaeroma has been greatly underestimated. Unlike the other borers described, works in either fresh or salt water. The St. John River at Palatka, Fla., is one hundre miles from the sea, and practically fresh the year around, yet piling was found badly infested and in some cases destroyed. The author has found it working in the St. Johns River at Jacksonville, Fla., and at Mayport, Fla., which is within two miles of the Atlantic Ocean. At the latter place, its ravages were of more consequence than those of th shipworm and liminoria combined. It was also found to be very numerous at Brunswick, Ga., Charleston, S. C., and at Tampa, Fla. It has previously been re- ported in a bayou near Slidell, La., and it seems reasonable that this borer may be present along the entire coast line from New Orleans to Charleston, S. C.

All the borers work from the high tide level to many feet below the surface. The damage is most evident action of the waves in breaking away the wood. Typical illustrations of the work of the various borers are shown in Figs. 7, 8 and 9. Fig. 7 shows a longleaf pine pile destroyed at Brunswick, Ga., by liminoria. Fig. 8 was taken at Pensacola, Fla., and shows a pine pile destroyed by xylotrya. Fig. 9 is of a pine pile at Mayport, Fla., destroyed by sphaeroma. It is evident that the destruction of this pile might easily have been mistaken for that caused by shipworms. No illustration is available of a pile destroyed by chelura. At $B$, Fig. 2 , is shown a specimen of palmetto from the St. Johns River at Mayport, Fla., attacked by sphaeroma. This species is generally considered to be immune from attack by borers.

Exact knowledge of the range and extent of the activity of chelura and sphaeroma is lacking. It would aid in the advancement of science, therefore, if those readers who have an opportunity to observe the destruction of timber by marine wood borers would report the presence of these two borers, wherever found, to the Forest Products Laboratory, Madison, Wis., sending samples of the borers for proper identification. blowing machines. The second apparatus is the strike which works against the lever of the spark plug. Two of these devices can be seen in the openings of the cylinder casing of the gas engine; and a detail view is als given. At the spark plug inside the engine is a fixed contact against which works a movable electric contact mounted on a rod which passes outside, and is adapted to be worked by a striker, this latter hitting a short lever on the end of the rod so as to cause the break of current at the spark plug. The device here shown consists of a magnet core or armature working on a pivo and carrying a hammer. When the rotary device on the cam shaft closes the electric circuit for the spark plug, the core is attracted by the magnet with a sudden movement, and the hammer strikes the spark plug lever and breaks contact, thus making the arc or spark for the ignition. When the spark ceases the current is broken

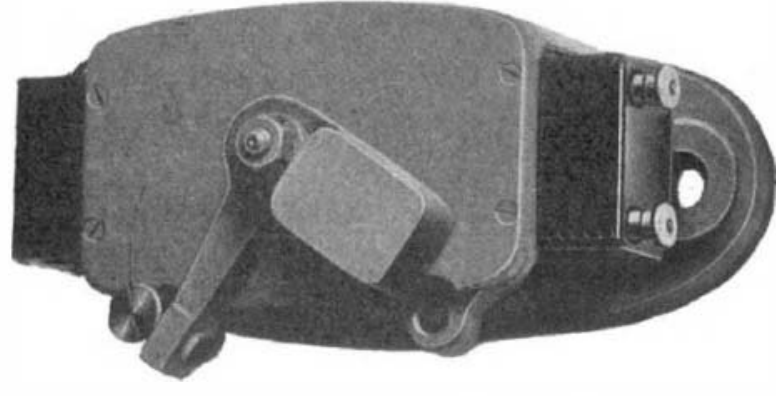

Electrical contact-breaker device. and the apparatus loses its magnetism, so that the hammer comes back to zero by a suitable counterweight. Besides being very reliable in operation, this electrically operated break has the advantage that it will work well upon all tensions of direct current between 65 and 220 volts.

\section{A Museum of Crime}

To Prof. Hans Gross of the University of Gratz, Austria, is due the credit of establishing the first museum of criminology and criminalistic laboratory, where the weapons, tools, and other paraphernalia and materials used by criminals are assembled to assist in the analysis of the workings of criminal minds and a study of methods and systems for dealing with this large and dangerous class of every community. This museum was established in 1895-1896, and since then other establishments of the same character have been organized, following the plans which he successfully formulated.

One of the most important of these is the Society of Criminology and Social Defense in Paris, which has a membership of over two hundred, including many prominent representatives of the law, the police and medical profession; and it was organized to concentrate and centralize the scattered efforts of individuals who were studying this disquieting social problem, and to make the results of their work available for mutual information. The valuable and extensive museum collection of the society was presented to it by M. Pechard, a former Superintendent of Police of Paris, and represents the gatherings of a lifetime.

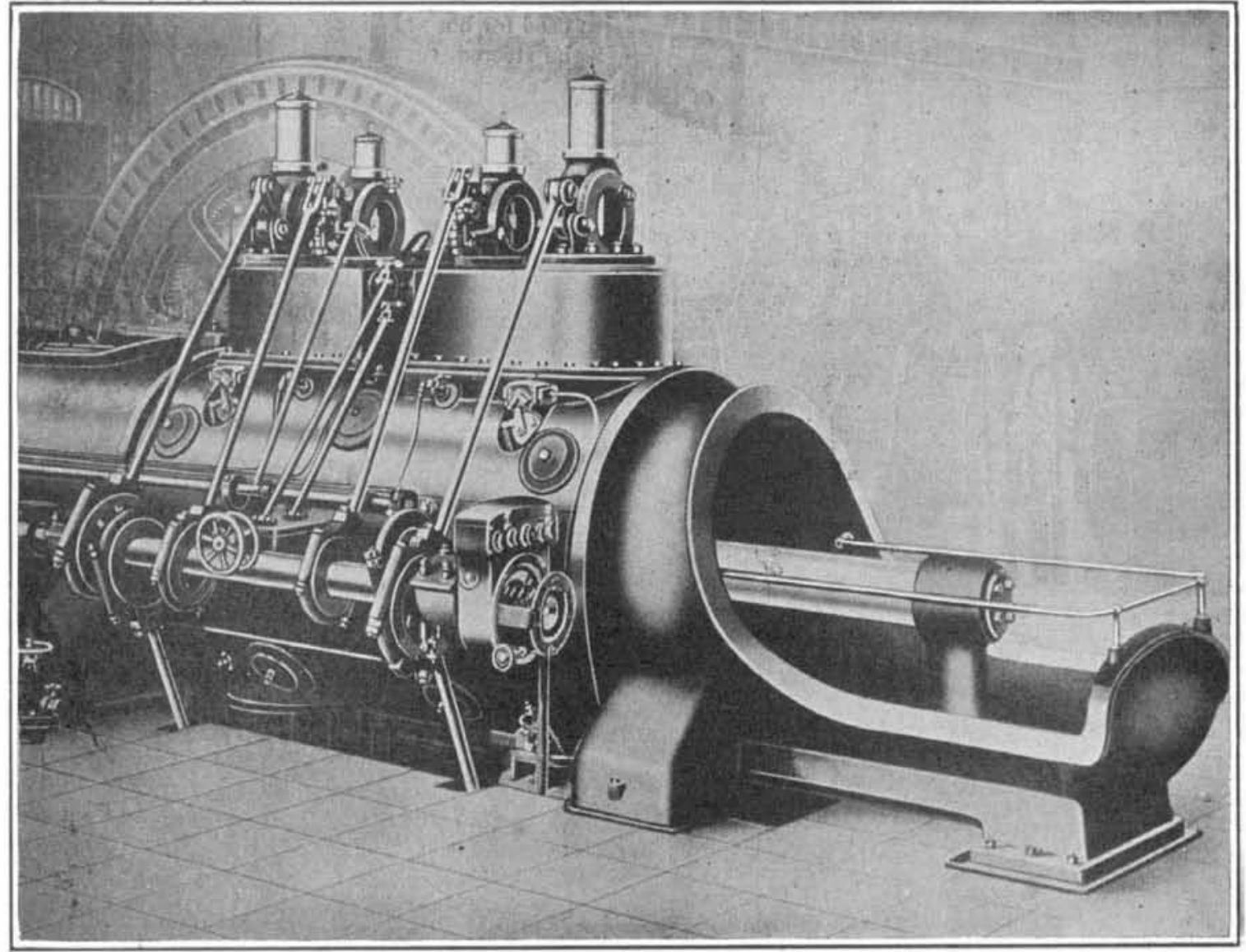

Rear cylinder of a large horizontal gas engine, showing electrical ignition apparatus on end of camshaft, and contact breakers in openings of the cylinder casing. 